\title{
Mass-Tag Technology Responding \\ to Intracellular Signals as a Novel Assay \\ System for the Diagnosis of Tumor
}

\author{
Jeong-Hun Kang and Yoshiki Katayama*t \\ CREST, Japan Science and Technology Corporation, Kawaguchi, Japan
}

Aishan Han
Riken, Wako, Japan

Shuhei Shigaki, Jun Oishi, Kenji Kawamura, Riki Toita, Xiao Ming Han,
Takeshi Mori, $^{+}$and Takuro Niidome
Department of Applied Chemistry, Faculty of Engineering, Kyushu University, Fukuoka, Japan

A novel mass spectrometry-based assay system for determining protein kinase activity employing mass-tagged substrate peptide probes was used for the diagnosis of tumors. Two peptide probes (H-type and D-type) were synthesized containing the same substrate peptide sequence for protein kinase $\mathrm{C}$ (PKC). The molecular weights of the two probes differ because of the incorporation of deuterium into the acetyl groups of the D-type probe. The lysates of the normal and tumor tissue were prepared and reacted with the H- and D-type peptide probes, respectively. The PKC activities of the normal and tumor tissues can be compared simply and directly by calculating the phosphorylated ratio to each peptide probe, obtained from the peak intensity of the mass spectrum after mixing of the two reaction solutions. The phosphorylation ratio for the reaction of the H-type peptide probe with the tumor tissue lysate (B16 melanoma) was more than three times higher than that of the D type peptide probe with the normal skin tissue lysate. These results show that the novel assay system for detecting protein kinase activity using mass-tag technology can be a simple and useful means to profile protein kinase activity for cell or tissue lysate samples, and can be applied to the diagnosis of tumors. (J Am Soc Mass Spectrom 2007, 18, 106-112) (C) 2007 American Society for Mass Spectrometry

$\mathrm{L}$ iving cells contain numerous signal transduction pathways that respond to extracellular signals to regulate or modulate the respective gene expressions. Extracellular signals either penetrate the cellular membrane or bind to the extracellular domain of the receptors. These activated receptors are able to change the amount or intracellular distribution of second messengers through the use of effectors. The second messengers also activate the protein targets that control the final gene expression by acting on targets further downstream. In these intracellular signal transduction pathways, phosphorylation by protein kinases is one of the most versatile processes in cellular growth and function through activation of the target proteins [1,2].

Protein kinase C (PKC), a phospholipid-dependent

Published online October 13, 2006

Address reprint requests to Dr. Y. Katayama, Department of Applied Chemistry, Faculty of Engineering, Kyushu University, 744 Motooka, Nishi-ku, Fukuoka 819-0395, Japan. E-mail: ykatatcm@mbox.nc.kyushu-u.ac.jp

* Also affiliated with the Department of Applied Chemistry, Faculty of Engineering, Kyushu University, Fukuoka, Japan.

† Also at the Center for Future Chemistry, Kyushu University, Fukuoka, Japan. serine/threonine kinase, appears to be involved in the signal transduction response to a variety of hormones and growth factors. The phosphorylation of serine or threonine residues by PKC has an important influence on diverse biological phenomena such as signal transduction, cell division and motility, apoptosis and carcinogenesis $[3,4]$.

PKC isozymes are classified into three subfamilies based on structural and activational characteristics: conventional or classic PKCs (cPKCs; $\alpha, \beta$, and $\gamma$ ), novel or nonclassic PKCs (nPKCs; $\delta, \varepsilon, \eta$, and $\theta$ ), and atypical PKCs $(\zeta, \iota$, and $\lambda)[3,4]$. The activation of cPKCs requires diacylglycerol (DAG) as an activator and phosphatidylserine (PS) and $\mathrm{Ca}^{2+}$ as activation cofactors. The $\mathrm{nPKC}$ are regulated by DAG and PS, but do not require $\mathrm{Ca}^{2+}$ for activation. In the case of atypical PKCs, their activity is stimulated only by PS, and not by DAG and $\mathrm{Ca}^{2+}[3,4]$.

In many diseases, extraordinary activation of certain protein kinases has been reported. For example, overexpression or hyperactivation of PKC $\alpha$ has been reported in several cancer cells or tissues (e.g., melanoma, breast cancer, and hepatoma) as having increased [3-7]. 


$$
\begin{aligned}
& \mathrm{O}=\overbrace{\mathbf{C} \mathbf{H}_{3}}^{\mathbf{C H}_{3}} \\
& \mathrm{~K}-\mathrm{AAFKKQGSFAKKK}
\end{aligned}
$$

H-type peptide probe $\quad$ M.W. 1649.1

Figure 1. H-type and D-type peptide probe.

Therefore, the detection of protein kinase activity is an important issue in the diagnosis and treatment of diseases or in drug development.

The most common protein kinase activity assay is the radioactive assay based on the use of $\left[{ }^{32} \mathrm{P}\right] \mathrm{ATP}$ in the phosphorylation of specific peptides or proteins. However, this method presents some disadvantages, such as the short half-life of ${ }^{32} \mathrm{P}$ isotope, the generation of hazardous ionizing radiation, and the difficulty in isolating the phosphorylated substrates [8]. For these reasons, a number of nonradioactive assays such as biosensors [8], fluorometric assay [9, 10] and ELISA [11, 12] were developed recently for measuring protein kinase activities. We previously reported a novel assay system (defined as mass-tag technology) for determining protein kinase activity, using mass-tagged substrate peptide probes and mass spectrometry. This method is a simple and sensitive method to profile the protein kinase activity [13].

In the present study, the mass-tag technology responding to intracellular signals, especially $\mathrm{PKC} \alpha$, was developed as a novel assay system for the diagnosis of tumors. This study showed that the mass-tag technol- ogy is a simple and useful method to profile the protein kinase activity in vivo and could be applied for the diagnosis of tumor.

\section{Experimental}

\section{Synthesis of Mass-Tag Probe}

Peptide probes containing the originally-designed substrate sequence of PKC (FKKQGSFAKKK), bearing a Lys and two Ala residues at the N-terminus, were synthesized using an automatic peptide synthesizer according to standard Fmoc-chemistry: two Ala gave no effect on the phosphorylation of peptide probes. Two normal acetyl groups $\left(\mathrm{CH}_{3} \mathrm{CO}-\right)$ or deuterated acetyl groups $\left(\mathrm{CD}_{3} \mathrm{CO}\right)$ were incorporated into the Lys residue at the N-terminus (Figure 1). After treatment with TFA, the peptide was purified on an Inertsil ODS-3 column ( $250 \times 20 \mathrm{~mm}, 3.5 \mu \mathrm{m}$, GL Sciences Inc., Tokyo, Japan) using a BioCAD Perfusion Chromatography system (Ikemoto Scientific Technology Co., Tokyo, Japan) under a linear A-B gradient, at a flow-rate of $8 \mathrm{ml} / \mathrm{min}$, where eluent $\mathrm{A}$ was $0.1 \%$ TFA in water and eluent $\mathrm{B}$ was $0.1 \%$ TFA in acetonitrile.

\section{Lysate Preparation from Tissues}

In the present study, all animal studies were performed in accordance with the Guidelines for Animal Experiments of the Kyushu University.

B16 melanoma cells were maintained in Dulbecco's modified Eagle's medium (DMEM) (Gibco Invitrogen

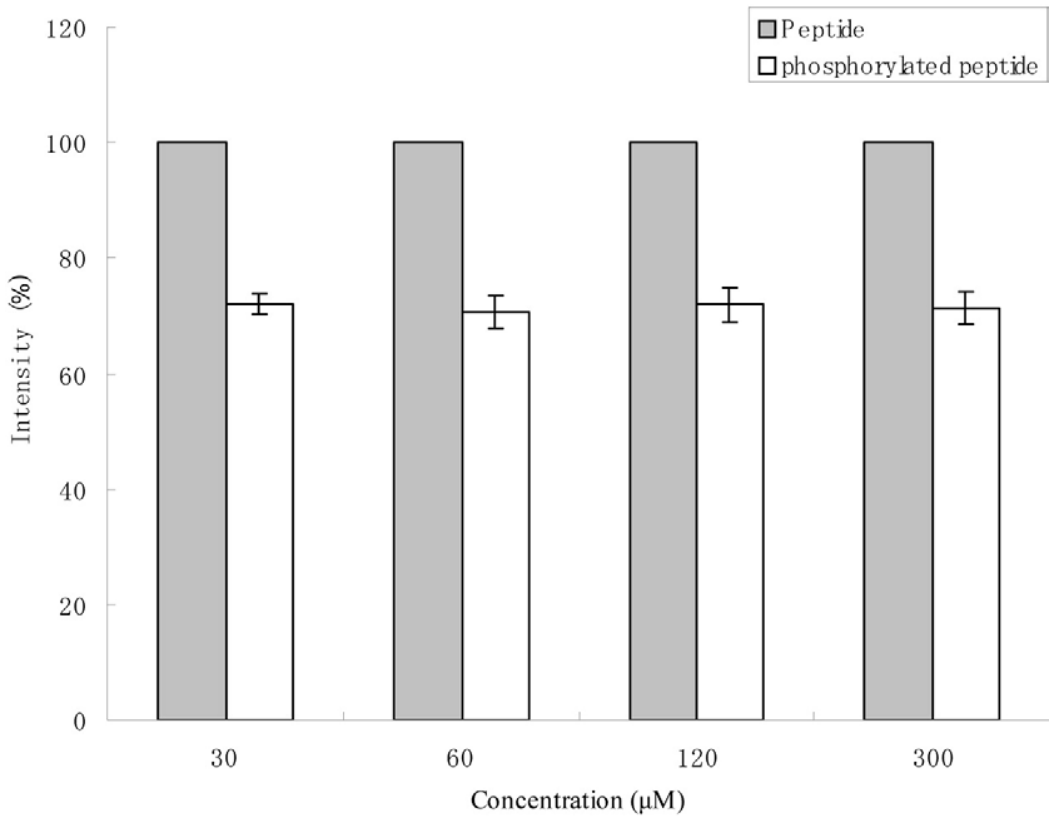

Figure 2. Ionization efficiency of the phosphorylated and the unphosphorylated peptide. Two peptides, AAFKKQGSFAKKK and its phosphorylated peptide (AAFKKQGphosphoSFAKKK) containing a phosphorylated Ser at the phosphorylation site, were synthesized. Two peptide solutions were mixed in a ratio of 1:1 (vol/vol) at concentrations of 30,60,120, and $300 \mu \mathrm{M}$, combined with CHCA, and then identified by MALDI-TOF mass spectrometry. 
Tumor cell or tissue
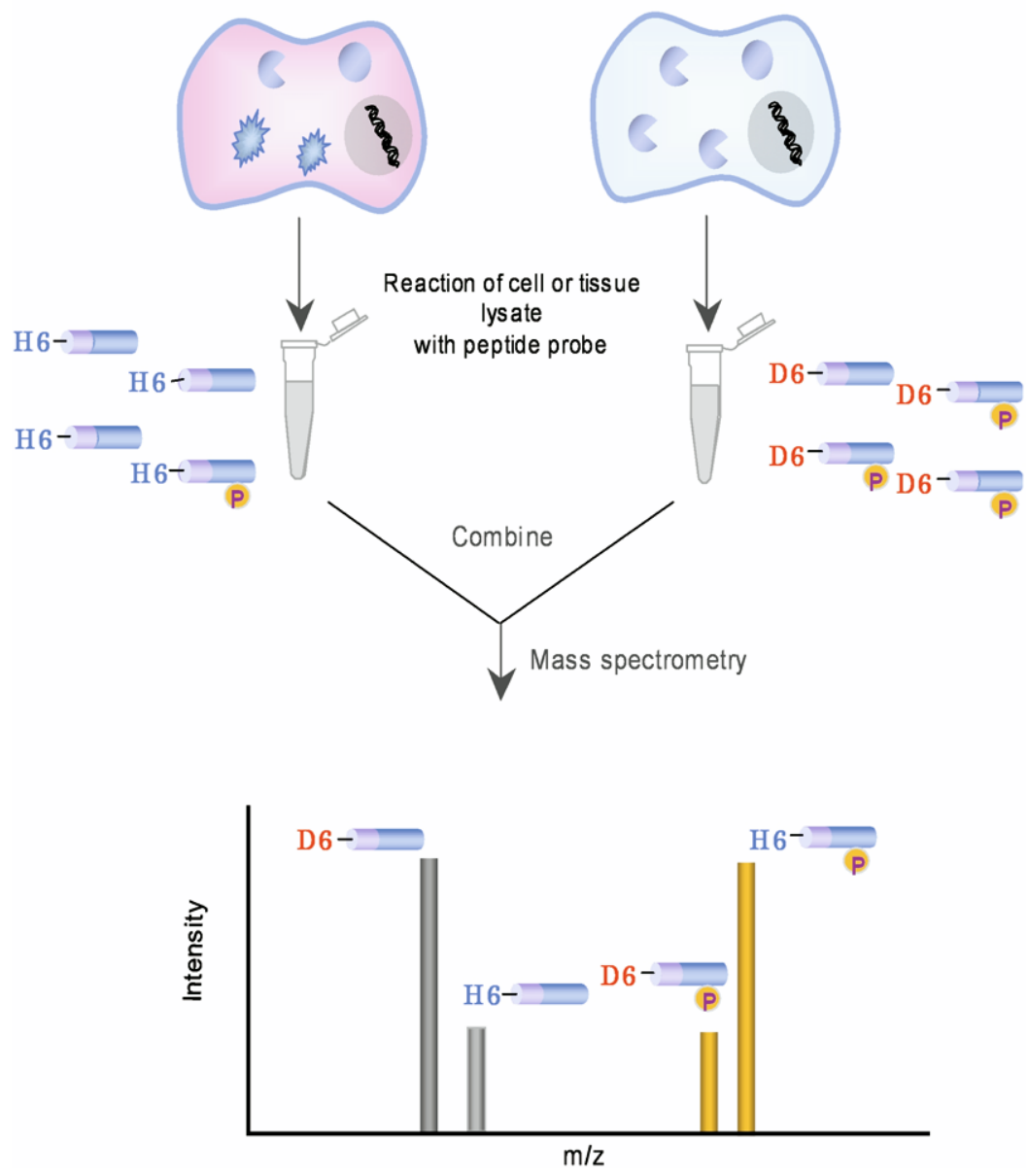

Figure 3. Schematic illustration of the detection principle of mass-tag technology for the diagnosis of tumors.

Co., Grand Island, NY) supplemented with $10 \%$ fetal bovine serum, penicillin $(100 \mathrm{U} / \mathrm{ml})$, streptomycin $(100$ $\mu \mathrm{g} / \mathrm{ml})$, and amphotericin B $(0.25 \mu \mathrm{g} / \mathrm{ml})$. The cells were kept in a humidified atmosphere containing $5 \%$ $\mathrm{CO}_{2}$ and $95 \%$ air at $37^{\circ} \mathrm{C}$.

Male 5-week old Kud:ddY mice, weighting $\sim 25 \mathrm{~g}$, were used in this study. The dorsal side was shaved and was inoculated subcutaneously with $1 \times 10^{6}$ cells per $100 \mu \mathrm{l}$ of Hanks' balanced salt solution (Gibco) per animal. Tumors were allowed to grow to a mean diameter of $\sim 0.7$ to $1.0 \mathrm{~cm}$.

Mice were sacrificed and the tumors were excised. After the tumors were weighed, they were homogenized in $10 \mathrm{ml}$ of buffer [20 mM Tris-HCl, pH 7.5, 250 $\mathrm{mM}$ sucrose, and protease inhibitor-EDTA free (Roche, Tokyo, Japan)]. The homogenate was centrifuged at $1000 \times g$ at $4{ }^{\circ} \mathrm{C}$ for $10 \mathrm{~min}$ and the supernatant was removed. After washing with $5 \mathrm{ml}$ of buffer and recentrifuging, $1 \mathrm{ml}$ of buffer was added into the precipitate and then sonicated. After sonication, the samples were centrifuged at $5000 \times g$ at $4{ }^{\circ} \mathrm{C}$ for $15 \mathrm{~min}$, and the resulting supernatant was used as whole lysate sample for the phosphorylation reactions. The lysate of normal skin tissue was also prepared by the same method.

\section{Phosphorylation Reaction for Each Peptide Probe}

The Phosphorylation reaction for each peptide probe was carried out in $50 \mu \mathrm{l}$ of buffer $(20 \mathrm{mM}$ Tris- $\mathrm{HCl}, \mathrm{pH}$ 7.5, $10 \mathrm{mM} \mathrm{MgCl} 2,0.5 \mathrm{mM} \mathrm{CaCl}, 200 \mu \mathrm{M}$ ATP, 2.0 $\mu \mathrm{g} / \mathrm{ml} \mathrm{DAG}$, and $2.5 \mu \mathrm{g} / \mathrm{ml}$ PS) containing $30 \mu \mathrm{M}$ peptide probe and tissue lysate at a $200 \mu \mathrm{g} / \mathrm{ml}$ protein concentration. After the phosphorylation reaction for $120 \mathrm{~min}$ at $37^{\circ} \mathrm{C}$, two solutions for the D-type and $\mathrm{H}$-type peptides were combined and identified by matrix-assisted laser desorption/ionization-time-offlight (MALDI-TOF) mass spectrometry using a Voyager DE RP Biospectrometry Workstation (Applied Biosystems, Framingham, MA) in positive ion reflectron mode. The $\alpha$-cyano-4-hydroxycinnamic acid (CHCA) matrix $(10 \mathrm{mg} / \mathrm{ml})$ was prepared in $50 \%$ water/acetonitrile and $0.1 \%$ TFA. The matrix and sample were mixed in a ratio of 1:1 (vol/vol). A total volume (1 $\mu 1)$ of the mixture was applied on the sample plate and allowed to dry to induce crystallization, and then analyzed by MALDI-TOF mass spectrometry. The accelerating voltage was $20 \mathrm{kV}$ with a $100 \mathrm{~ns}$ extraction delay time. Typically, 100 laser shots were averaged to improve the signal-to-noise ratio. All spectra were an- 


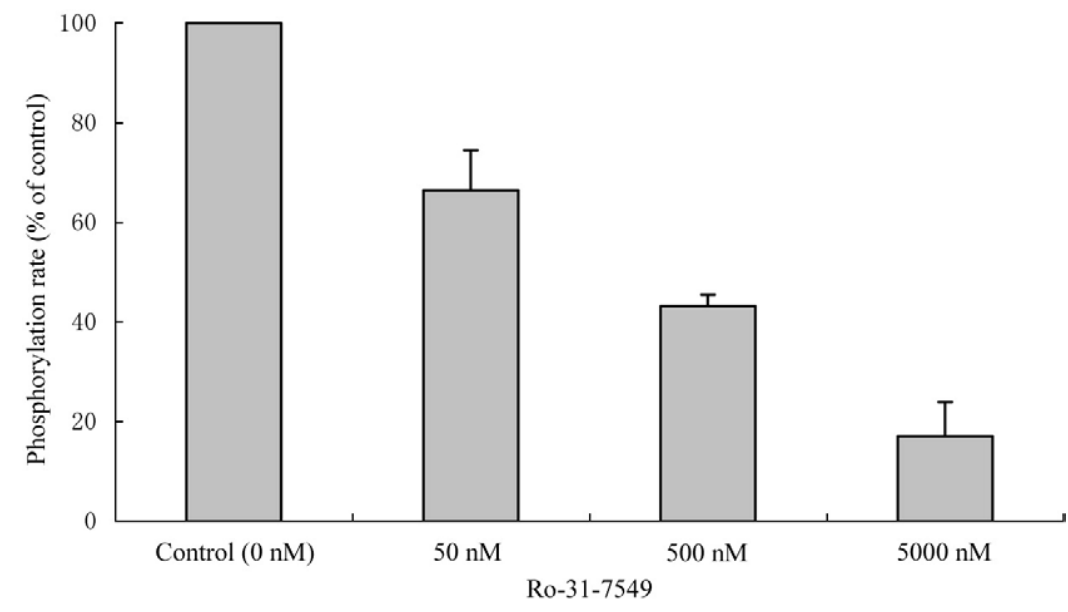

Figure 4. Changes of phosphorylation rate for probe peptides after adding the PKC inhibitor Ro-31-7549. PKC inhibitor was added into each well containing $1 \times 10^{6}$ B16 melanoma cells at concentrations of $0,50,500$, or $5000 \mathrm{nM}$. After $6 \mathrm{~h}$, cells were scraped and lysed by sonication. The samples were centrifuged at $5000 \times g$ at $4{ }^{\circ} \mathrm{C}$ for $15 \mathrm{~min}$, and the supernatant was used as lysate samples for the phosphorylation reaction.

alyzed using Data Explore software (Applied Biosystems). The phosphorylation ratio for each peptide probe was calculated by the formula, [phosphorylated peptide probe/(phosphorylated peptide probe + unphosphorylated peptide probe) $\times 100]$.

Moreover, for the accurate estimation of phosphorylation ratio, we synthesized two peptides, AAFKKQGSFAKKK and its phosphorylated peptide (AAFKKQGphosphoSFAKKK) containing the phosphorylated Ser at the phosphorylation site. Two peptide solutions were mixed in a ratio of 1:1 (vol/vol) at concentrations of 30, 60,120 , and $300 \mu \mathrm{M}$, combined with CHCA, and then analyzed by MALDI-TOF mass spectrometry. As

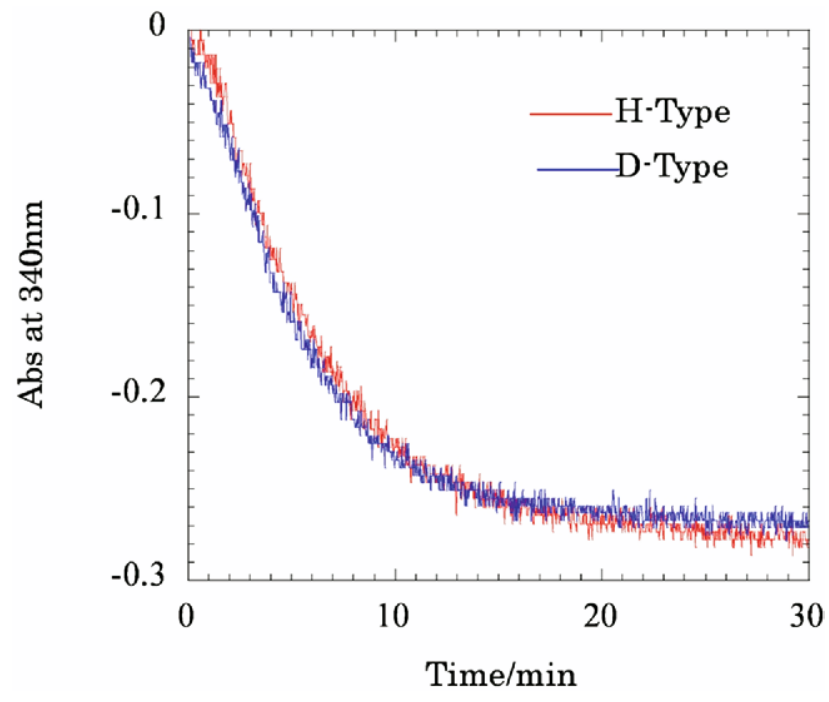

Figure 5. Coupled enzyme assay of each peptide probe to identify a difference in the phosphorylation rate between the two peptide probes (H-type and D-type). After the phosphorylation reaction of the two peptide probes (H-type and D-type) with $\mathrm{PKC} \alpha$, the concentration of NADH was monitored spectrophotometrically at $340 \mathrm{~nm}$. shown $^{\circ}$ in $^{\circ}$ Figure $^{\circ} 2,^{\circ}$ the ${ }^{\circ}$ intensity ${ }^{\circ}$ in ${ }^{\circ}$ phosphorylated peptide was 1.2 times as low as it in nonphosphorylated peptide in all concentrations. From these results, the phosphorylation ratio was corrected by 1.2.

\section{Coupled Enzyme Assay}

The coupled enzyme assay was performed according to a method previously described with minor modifications ${ }^{\circ}\left[12 .^{\circ}{ }^{\circ}\right.$ Exactly $^{\circ} 100^{\circ} \mu \mathrm{M}^{\circ}$ the ${ }^{\circ}$ peptide $^{\circ}$ probe $^{\circ}$ was incubated in $500 \mu \mathrm{l}$ of $20 \mathrm{mM}$ Tris- $\mathrm{HCl}$ buffer solution (pH 7.5) containing $1 \mathrm{mM}$ phosphoenolpyruvate, 0.3 $\mathrm{mM} \mathrm{NADH}, 12 \mathrm{U} / \mathrm{ml}$ lactate dehydrogenase (LDH), 4 $\mathrm{U} / \mathrm{ml}$ pyruvate kinase, $10 \mathrm{mM} \mathrm{MgCl}, 0.5 \mathrm{mM} \mathrm{CaCl}$, $200 \mu \mathrm{M}$ ATP, $2.0 \mu \mathrm{g} / \mathrm{ml}$ DAG, $2.5 \mu \mathrm{g} / \mathrm{ml}$ PS, and $1 \mathrm{ng} /$ $\mathrm{ml}$ PKC $\alpha$. The reaction was initiated by the addition of ATP to buffer and was performed for $60 \mathrm{~min}$ at $37^{\circ} \mathrm{C}$. The diminution of NADH was detected with an UV/ VIS spectrophotometer (model V-560, JASCO International Co., Tokyo, Japan), equipped with an ETC-505T temperature controller (JASCO) at $340 \mathrm{~nm}$.

\section{Inhibition of PKC $\alpha$ by the Addition of PKC Inhibitor (Ro-31-7549) to B16 Melanoma Cells}

$1 \times 10^{6}$ cells were seeded into wells and incubated in a humidified atmosphere containing $5 \% \mathrm{CO}_{2}$ and $95 \%$ air at $37^{\circ} \mathrm{C}$. After $24 \mathrm{~h}$, PKC inhibitor (Ro-31-7549) was added into each well at concentrations of 0,50 , 500 , or $5000 \mathrm{nM}$. After $6 \mathrm{~h}$ from the addition of PKC inhibitor, cells were scraped and lysed in buffer [20 $\mathrm{mM}$ Tris- $\mathrm{HCl}, \mathrm{pH} 7.5,250 \mathrm{mM}$ sucrose, and protease inhibitor-EDTA free] by sonication. The samples were centrifuged at $5000 \times g$ at $4{ }^{\circ} \mathrm{C}$ for $15 \mathrm{~min}$ and the supernatant was used as lysate samples for the phosphorylation reaction. 

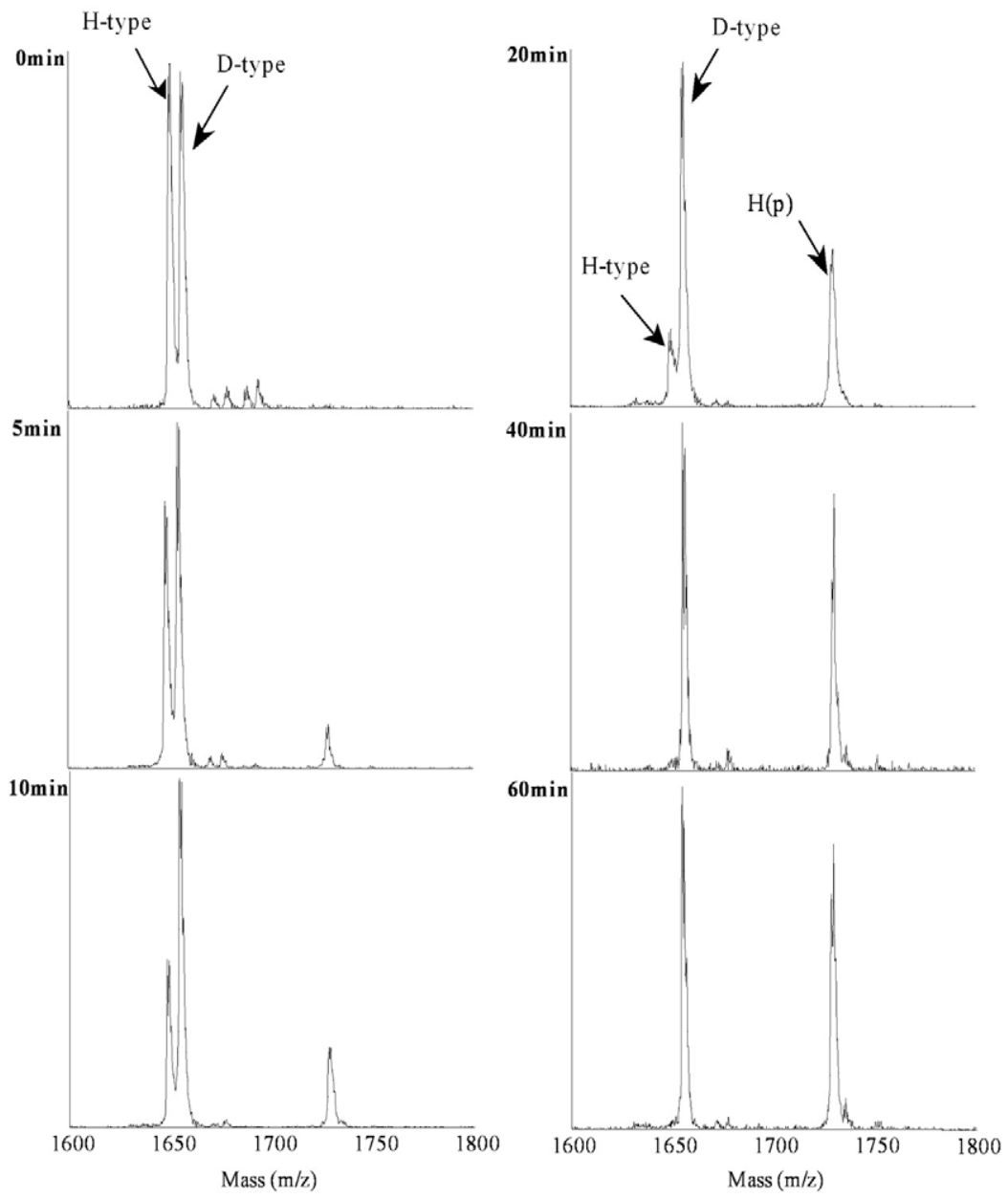

Figure 6. Phosphorylation reaction of each peptide probes in the absence or presence of PKC $\alpha$. The $\mathrm{H}$-type and D-type peptide probes were phosphorylated in the presence or absence of PKC $\alpha$ at $37{ }^{\circ} \mathrm{C}$ for $60 \mathrm{~min}$, respectively, and the mixture of the H-type and D-type samples was detected using mass spectrometry. $\mathrm{H}(\mathrm{p})$, phosphorylated $\mathrm{H}$-type peptide probe.

\section{Results and Discussion}

\section{Detection Principle of Mass-Tag Technology}

The detection principle of mass-tag technology is presented ${ }^{\circ}{ }^{\circ}{ }^{\circ}$ Figure $^{\circ} 3 .^{\circ}$ Two $^{\circ}$ types ${ }^{\circ}$ of ${ }^{\circ}$ peptide ${ }^{\circ}$ probes (H-type and D-type) containing the same substrate peptide sequence for the target protein kinase show different molecular weights because of the hydrogenated (H-type) and deuterated (D-type) acetyl groups at the amino-terminus. The lysate of normal skin or melanoma tissue was prepared and reacted with the H-type or D-type peptide probes, respectively. If each peptide probe is phosphorylated by the target protein kinase, the $\mathrm{m} / \mathrm{z}$ values of these probes increase by +80 $\mathrm{Da}$ in the mass spectrum. Therefore, protein kinase activities between normal and tumor tissue can be compared simply and directly by calculating the phosphorylated ratio to each peptide probe obtained from the peak intensity in the mass spectrum after mixing of two reaction solutions. Mass spectrometry has become the core instrumental technology in re- cent postgenomic research because of its high sensitivity ${ }^{\circ}{ }^{\circ}{ }^{\circ}$ accuracy $\left[14^{\circ}-16\right] .{ }^{\circ}$ However, ${ }^{\circ}$ mass ${ }^{\circ}$ spectroscopy is generally disadvantaged by the poor reproducibility among independent measurements. Thus, stable isotope labeling is a promising way of overcoming this problem.

\section{Phosphorylation of Substrate Peptide by Six PKC} Isozymes $(\alpha, \beta, \delta, \eta, \varepsilon$, and $\zeta)$

$\operatorname{PKC} \alpha, \beta, \delta, \eta, \varepsilon$, and $\zeta$ are mostly detected in the normal skin $^{\circ}$ and $/$ or $^{\circ} \mathrm{B} 16^{\circ}$ melanoma ${ }^{\circ}$ tissues ${ }^{\circ}\left[6,{ }^{\circ} 17\right] . .^{\circ}$ Among ${ }^{\circ}$ these isozymes, hyperactivation of PKC $\alpha$ in tumor cells including melanoma cells has been reported. We designed an original peptide sequence for PKC $\alpha$ phosphorylation for use as mass-tagged probes. Then, two peptide probes (H-type and D-type) were phosphorylated by these six PKC isozymes. The two peptide probes showed a higher phosphorylation rate on PKC $\alpha(61-65 \%)$ than other PKC isozymes $(\beta, \delta, \eta, \varepsilon$, and $\zeta)(<20 \%)$ after $60 \mathrm{~min}$ reaction in 


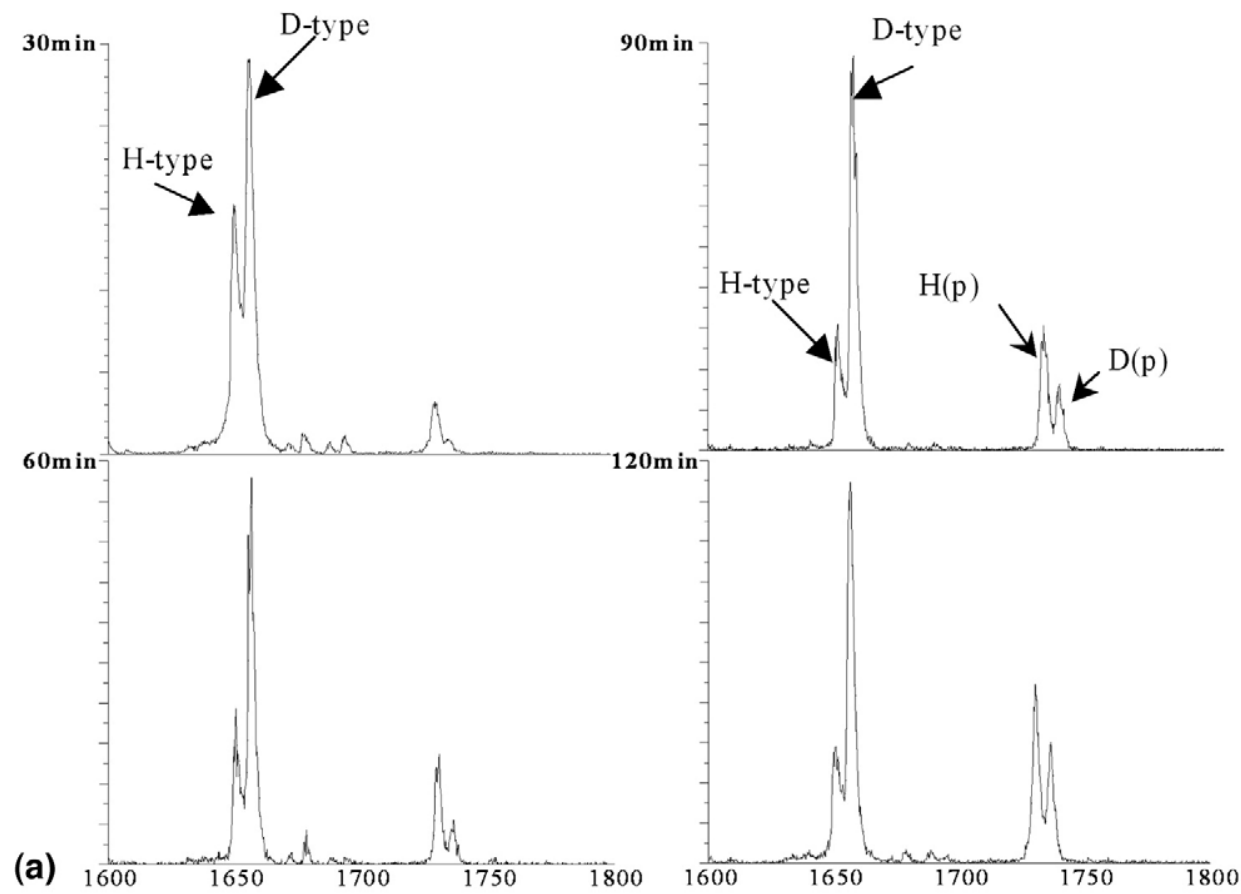

(a)

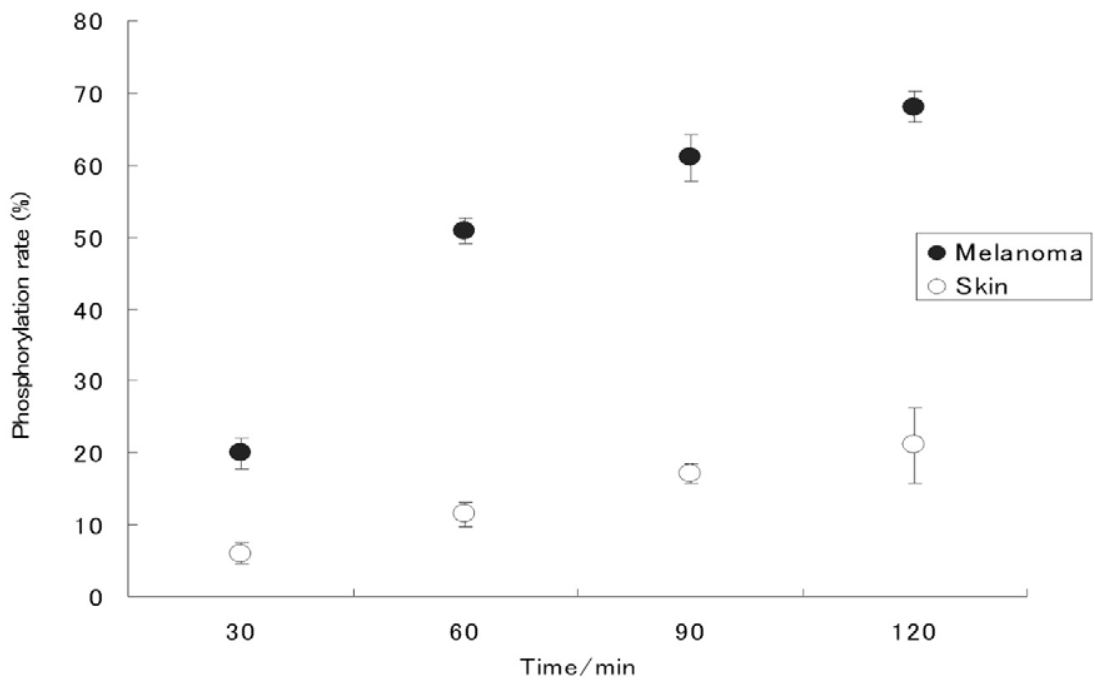

(b)

Figure 7. Phosphorylation reaction of each peptide probe with normal skin (open circle) or melanoma tissue lysate (filled circle). The H-type and D-type peptide probes were reacted with melanoma tissue lysate and with normal skin tissue lysate at $37^{\circ} \mathrm{C}$ for $120 \mathrm{~min}$, respectively, and the mixture of H-type and D-type samples was detected using mass spectrometry. (a) Typical mass spectra of unphosphorylated peptide probes and phosphorylated peptide probes. (b) Time-dependant change of the phosphorylation rate of two phosphorylated peptide probe. $\mathrm{H}(\mathrm{p})$, phosphorylated H-type peptide probe; $\mathrm{D}(\mathrm{p})$, phosphorylated D-type peptide probe.

the conditions described in the experimental section, at a $0.1 \mu \mathrm{g} / \mathrm{ml}$ enzyme concentration.

Moreover, the addition of Ro-31-7549 (a selective inhibitor of PKC) into B16 melanoma cells leads to a decrease in the phosphorylation rate for the probes. At a concentration of $5000 \mathrm{nM}$, a decrease of over $80 \%$ was identified compared $^{\circ}$ with $^{\circ}$ no $^{\circ}$ addition ${ }^{\circ}$ (Figure ${ }^{\circ}$ 4).$^{\circ}$ The $^{\circ}$ Ro-31-7549 selectively inhibits $\mathrm{PKC}$, especially $\mathrm{cPKC}$, by competing with ATP for the cosubstrate site. PKC $\alpha$ is inhibited by Ro-31-7549 with an $\mathrm{IC}_{50}$ value of $50 \mathrm{nM}$, but $\mathrm{IC}_{50}$ values of
$\mathrm{PKC}^{\circ} \beta^{\circ}$ or ${ }^{\circ} \gamma^{\circ} \mathrm{is}^{\circ}>160^{\circ} \mathrm{nM}^{\circ}\left[18,{ }^{\circ} 19\right] .{ }^{\circ}$ These ${ }^{\circ}$ results ${ }^{\circ}$ show $^{\circ}$ that the peptide probes used in this study may have specificity for $\operatorname{PKC} \alpha$.

\section{Coupled Enzyme Assay of Each Peptide Probe}

To confirm whether there is a difference in phosphorylation rate between the two peptide probes (H-type and D-type), the time courses of the phosphorylation in both probes were identified by a coupled enzyme assay. When 
the peptide probe is phosphorylated by PKC $\alpha$, ADP is produced from ATP. This ADP production is coupled with the pyruvate kinase and lactate dehydrogenase reactions for oxidizing NADH. Thus, the phosphorylation time course of the peptide probes by PKC $\alpha$ can be monitored by the decreasing absorbance at $340 \mathrm{~nm}$ for NADH.

The concentration of NADH was decreased in each peptide probe over time. In the present study, a difference in the phosphorylation rate between the two peptide probes was not found, meaning that they have the same phosphorylation ${ }^{\circ}$ sensitivity ${ }^{\circ}{ }^{\circ} \mathrm{PKC} \alpha^{\circ}$ (Figure ${ }^{\circ}$ ).

\section{Detection of the Phosphorylation Reaction of the Peptide Probe in the Presence of Isolated PKC $\alpha$}

The H-type peptide probe was phosphorylated in the presence of PKC $\alpha$ for $60 \mathrm{~min}$. On the other hand, the D-type peptide probe was incubated in the absence of PKC $\alpha$ at $37^{\circ} \mathrm{C}$ for $60 \mathrm{~min}$. The peak of the H-type peptide probe decreased gradually, while its phosphorylated peak increased. However, no change in the peak intensity from the D-type peptide probe was identified over $^{\circ}$ the ${ }^{\circ} 60^{\circ} \min ^{\circ}$ period $^{\circ}$ (Figure ${ }^{\circ}$ ).

\section{Phosphorylation Reaction of Each Peptide Probe with Normal Skin or Melanoma Tissue Lysate}

The H-type and D-type peptide probe were reacted with melanoma tissue lysate and with normal skin tissue lysate, respectively. The phosphorylation results for $^{\circ}$ each $^{\circ}$ peptide ${ }^{\circ}$ probe $^{\circ}$ are $^{\circ}$ presented $^{\circ}$ in $^{\circ}$ Figure $^{\circ} 7 .^{\circ}$ The peak of the H-type peptide probe decreased, but its phosphorylated peptide peak increased with the lapse of time. The phosphorylation rate for the H-type at 60 and $120 \mathrm{~min}$ was more than three times higher than that for the D-type, meaning that the PKC activity in melanoma tissue is higher that in normal skin tissue.

It is known that the activity of PKC, especially $\operatorname{PKC} \alpha$, is higher in melanoma cells or tissues than in normal skin cells or tissues. Moreover, there are many reports that the activator and cofactor (DAG, PS and $\mathrm{Ca}^{2+}$ ) concentrations and translations of PKC from cytosol to membrane ${ }^{\circ}$ increased ${ }^{\circ}{ }^{\circ}{ }^{\circ}$ melanoma ${ }^{\circ}$ cells $^{\circ}$ or $^{\circ}{ }^{\circ}$ issues ${ }^{\circ}[3-7$, 20]. Similarly, ${ }^{\circ}$ in $^{\circ}$ the ${ }^{\circ}$ present ${ }^{\circ}$ study, ${ }^{\circ}$ the ${ }^{\circ} P K C^{\circ}$ activity ${ }^{\circ}$ in melanoma tissue was significantly higher compared with that in normal skin tissue.

Mass-tag technology is broadly used to identify peptide and protein sequences responding to enzymes, drugs, ${ }^{\circ}$ or ${ }^{\circ}$ chemicals $^{\circ}\left[21,{ }^{\circ} 22\right] .{ }^{\circ}$ In $^{\circ}$ the ${ }^{\circ}$ study, ${ }^{\circ}$ mass-tag technology was applied for the diagnosis of tumor. Our study shows that the novel assay system of protein kinase activity using mass-tagged substrate peptide probes and mass spectrometry can be applied to the diagnosis of tumor. Moreover, our mass-tag technology is a simple and useful means to profile protein kinase activity for cell or tissue samples.

\section{Acknowledgments}

This research was performed under funding support from CREST, Japan Science and Technology Corporation, and New Energy and Industrial Technology Development Organization (NEDO).

\section{References}

1. Katayama, Y.; Fujii, K.; Ito, E.; Sakakihara, S.; Sonoda, T.; Murata, M.; Maeda, M. Intracellular Signal-Responsive Artificial Gene Regulation for Novel Gene Delivery. Biomacromolecules 2002, 3, 905-909.

2. Oishi, J.; Kawamura, K.; Kang, J. H.; Kodama, K.; Sonoda, T.; Murata, M.; Niidome, T.; Katayama, Y. An Intracellular Kinase Signal-Responsible Gene-Carrier for Cell Specific Gene Therapy. J. Control Release 2006, $110,431-436$.

3. Hug, H.; Sarre, T. F. Protein Kinase C Isoenzymes: Divergence in Signal Transduction? Biochem. J. 1993, 291, 329-343.

4. Newton, A. C. Regulation of Protein Kinase C. Curr. Opin. Cell Biol. 1997, 9, 161-167.

5. Mackay, H. J.; Twelves, C. J. Protein Kinase C: A Target for Anticancer Drugs? Endocr. Relat. Cancer 2003, 10, 389-396.

6. Lahn, M.; Sundell, K. L. The Role of Protein Kinase C-alpha (PKC- $\alpha$ ) in melanoma. Melanoma Res. 2004, 14, 85-89.

7. Jaken, S. Protein Kinase C and Tumor Promoters. Curr. Opin. Cell Biol. 1990, 2, 192-197.

8. Chen, C. A.; Yeh, R. H.; Yan, X.; Lawrence, D. S. Biosensors of Protein Kinase Action: From in Vitro Assays to Living Cells. Biochim. Biophys. Acta 2004, 1697, 39-51.

9. Viht, K.; Vaasa, A.; Raidaru, G.; Enkvist, E.; Uri, A. Fluorometric TLC Assay for Evaluation of Protein Kinase Inhibitors. Anal. Biochem. 2005, 340, 165-170.

10. Inamori, K.; Kyo, M.; Nishiya, Y.; Inoue, Y.; Sonoda, T.; Kinoshita, E.; Koike, T.; Katayama, Y. Detection and Quantification of On-Chip Phosphorylated Peptides by Surface Plasmon Resonance Imaging Techniques Using a Phosphate Capture Molecule. Anal. Chem. 2005, 77, 3979-3985.

11. Ross, H.; Armstrong, C. G.; Cohen, P. A Nonradioactive Method for the Assay of Many Serine/Threonine-Specific Protein Kinases. Biochem. J. 2002, 366, 977-981.

12. Sonoda, T.; Katayama, Y.; Maeda, M. A New Polymer Reagent for Monitoring of Protein Kinase A Activity Anal. Sci. 2001, 17, 277-279.

13. Sonoda, T.; Shigaki, S.; Nagashima, T.; Okitsu, O.; Kita, Y.; Murata, M.; Katayama, Y. Mass-Tag Technology for Monitoring of Protein Kinase Activity Using Mass Spectrometry. Bioorg. Med. Chem. Lett. 2004, 14, 847-850.

14. Liu, Z.; Schey, K. L. Optimization of a MALDI TOF-TOF Mass Spectrometer for Intact Protein Aanalysis. J. Am. Soc. Mass Spectrom. 2005, 16, 482-490.

15. Kammerer, B.; Frickenschmidt, A.; Gleiter, C. H.; Laufer, S.; Liebich, H. MALDI-TOF MS Analysis of Urinary Nucleosides. I. Am. Soc. Mass Spectrom. 2005, 16, 940-947.

16. Kang, J. H.; Toita, R.; Jiang, Y.; Niidome, T.; Katayama, Y. Simultaneous Analysis of Phosphorylated Peptides by MALDI-TOF MS. Chromatographia 2006, 63, 595-598.

17. Oka, M.; Kikkawa, U. Protein Kinase C in Melanoma. Cancer Metast. Rev. 2005, 24, 287-300.

18. Eilkinson, S. E.; Parker, P. L.; Nixon, J. S. Isoenzyme Specificity of Bisindolylmaleimides, Selective Inhibitors of Protein Kinase C. Biochem. J. 1993, 294, 335-337.

19. Murphy, C. T.; Westwick, J. Selective Inhibition of Protein Kinase C: Effect on Platelet Activating Factor Induced Platelet Functional Responses. Biochem. J. 1992, 283, 159-164.

20. Yamanishi, D. T.; Meyskens, F. L., Jr. Alterations in Gene Expression and Signal Transductions in Human Melanocytes and Melanoma Cells. Crit. Rev. Oncogene 1994, 5, 429-450.

21. Zabrouskov, V.; Senko, M. W.; Du, Y.; Deduc, R. D.; Kelleher, N. L. New and Automated $\mathrm{MS}^{\mathrm{n}}$ Approaches for Top-Down Identification of Modified Proteins. J. Am. Soc. Mass Spectrom. 2005, 16, 2027-2038.

22. Jin, M.; Bateup, H.; Padovan, J. C.; Greengard, P.; Naim, A. C.; Chait B. T. Quantitative Analysis of Protein Phosphorylation in Mouse Brain by Hypothesis-Driven Multistage Mass Spectrometry. Anal. Chem. 2005, $77,7845-7851$. 